\title{
Social and Political Transformation in the Czech Republic*
}

\author{
PAVEL MACHONIN ${ }^{\star *}$ \\ Institute of Sociology, Academy of Sciences of the Czech Republic, Prague
}

\begin{abstract}
The most apparent recent social change in the Czech Republic is the emergence of a new class structure. A large percentage of the population began their private activities in small business, while a part of them managed to become middlescale entrepreneurs. During the privatisation of the large companies, realised mostly by the voucher method, different groups competed to achieve positions in the top economic elite. Analyses of social mobility and of the factors of the income distribution have shown that the following groups have a higher chance of being successful in the ongoing social de-equalisation: the younger generations, bettereducated people, managers and private entrepreneurs and those former Communists who left the party after the political changes in 1989. These social processes are being accompanied by a gradual change in the political elite. In this field, the most successful are the younger middle-aged, new political activists pushing through the radical liberal economic reform. In spite of the clearly right-wing character of the ruling coalition, a democratically acquired social consensus exists for the time being, although some signs of social and political polarisation are visible. In the near future, two main alternatives of development are possible: a) the continuation of the liberal democratic reforms (whether it be a conservative, centrist or left democratic variant or a compromise combination of them is of less importance) and b) a populist and authoritarian interruption of the transformation processes (be it a radical leftist or rightist variant). The realisation of the first alternative is not only desirable from the point of view of joining the European Union in the foreseeable future, but also more likely given both the objective and subjective conditions within the Czech Republic.
\end{abstract}

Czech Sociological Review, 1994, Vol. 2 (No. 1: 71-87)

Post-communist societal changes are indisputably substantial and therefore also complex. They cannot be reduced to mere economic transformations, nor even to a simple combination of changes in economics, technology and education. Some crucial shifts in the social and political sphere, such as the installation of democratic political institutions and a reversal in the beliefs of numerous groups of people, can be considered the preconditions of the global societal changes. Some other social and political processes,

*) This article is based on a contribution to the international research project „East Central Europe 2000" sponsored by the Commission of the European Communities. The project was co-ordinated by the Institute for Human Sciences in Vienna and by the European Institute for Regional and Local Development in Warsaw. At the same time, in the text some preliminary data are used from the international comparative survey on ,Social Stratification and Circulation of Elites in the Eastern Europe" led by UCLA and sponsored by the U. S. National Science Foundation (USA) and NWO (Netherlands), in which both authors participated. The basic interpretations of data and general ideas are identical with those developed in the framework of a grant awarded by the Grant Agency of the Academy of Sciences, Czech Republic (,Social Stratification and Dynamics of the Post-Communist Transformation in the Czech and Slovak Republics“).

**) Direct all correspondence to Doc. PhDr. Pavel Machonin, DrSc., Institute of Sociology AS CR, Jilská 1, 11000 Praha 1. 
such as the emergence of a new social stratification and of corresponding workmotivation, or of liberal forms of behaviour, can be seen rather as the inevitable consequences of a large number of accumulated changes within the society as a whole, but more especially in the economy. Many of them, as, for example, the assertion of meritocratic principles as the basis for social justice or the creation of space for freedom of opinion and action, count among the crucial and highly-rated goal qualities of the presupposed „better future" in the former state socialist countries.

Since a political system can clearly be conceived as the most important sphere of institutionalised social structures, it invites the treatment of both social and political problems in the one paper, as, for instance, in the thematic study on social and political spheres written for the purposes of the project ECE 2000 [Machonin 1993b]. (Here we will emphasise the problem of the exchange of the political elites which seems to be an important factor in the changes in the social structure.)

We know quite well what kind of social and political system we are abandoning. However, the crucial questions remain: Where are we going? What will the nature of the emerging new society be? Which social forms will carry the development over from yesterday to tomorrow?

On a prior occasion [Machonin 1992: 125-133; 1993a: 2-7], we discussed extensively two possible theoretical and methodological approaches to looking for answers to these questions. Both the advantages and the inadequacies of the rather normative „transition approach" and the more realistic and empirically based „transformation approach" were pointed out. Our conclusion stated a preference for the concept of social transformation and its corresponding methodology. That does not mean that normative elements should be fully neglected in considerations of the future of the Czech Republic. Any social prognosis which attempts to predict stages of future development has to apply some elements of the teleological or normative imagination. This is particularly important in the case of this study as its primary task consists in defining the inevitable or preferable social and political characteristics with view to a particular end, i.e. joining the European Community in an historically short period.

\section{Changes in the social structure}

We conceive the post-communist transformation as a far-reaching historical change of social structures. Our consideration of the characteristics of the state socialist social system which operated in the Czech lands from 1948, on the reasons for its collapse and the social forces engaged in the events of 1989, and on its legacy, still strongly influencing the course of the social transformation, have recently been published in this journal [Machonin 1993c: 231-249]. Thus, we can focus our attention immediately on the changes that occurred in the Czech society in the first phase of social transformation, i. e. between November 1989 and the beginning of 1993.

What has really happened in the life of Czech society over the last four years, a period which has proved so rich in crucial political shifts? The presentation of evidence concerning the changes in technology, science, and education was the subject of a special thematic study under the auspices of ECE 2000. [Müller 1993] However, two points in this field which proved important for social changes should be given brief, but explicit, elaboration here. First, the Czech lands' civilisation and its cultural position behind the advanced European countries, typical of the state socialist countries in Europe and 
forming a part of the „legacy“ of the old system clearly influencing the present situation [Machonin 1993c: 242-244], is so substantial that it simply could not have been overcome in four years. This consideration is important to the characteristics of social structure such as the obvious survival both of the inherited „over-industrialised“, and therefore conservative, branch structure of the national economy which underwent minor alterations as well as a high share of the manual workers among the labour force (still about 54\% of all employees) [Data 1993]. Secondly, from our point of view, it is highly questionable whether in this short period, full of dramatic political events as it is, even the basic institutional presuppositions of further civilisation and cultural progress have been created. It is almost certain that in areas such as science, education, health services and culture that, because of the lack of financial resources and of sufficiently prepared projects, they simply did not come into being; nor has much been done in the sphere of technological progress.

Leaving aside the economic changes that are the subject of a parallel economic study [Sojka et al. 1993] (but keeping in mind their social consequences), we will start with a step , in medias res“, i.e. with an analysis of the emergence of a new class structure based on the differing positions of people within the system of the ownership of production means or other economic capitals. Plainly put, we are talking about a renaissance of class relationships in the original Marxist sense. This type of class relationships was administratively abolished during the second half of the 1940s and in the 1950s in both Czechoslovakia's republics. At the end of the 1980s, besides a small group of surviving elderly individual peasants, only about 65,000 self-employed people worked in communal services, accommodation and the like with official permission [Pøehled 1993: VI]. In the "second society“, of course, in many both officially acknowledged or simply tolerated forms including the "gray economy“ and home-work, many people prepared for the future expansion of private enterprise when political conditions would allow for it [Machonin 1993c: 237-238].

This expansion started in 1990 in five principal forms: a) „small privatisation“, involving mainly retail trade and services; b) restitutions partly concerning small enterprises in different branches, but mainly houses and land; c) that part of the so-called „large-scale privatisation“, in which conventional privatisation methods were used; d) the founding of new, predominantly small, firms; and e) that part of the „large-scale privatisation", in which the voucher method has been applied.

The social consequences of the first wave of privatisation - based mainly on forms a)-d) - evolved quite rapidly. Current statistics [Pøehled 1993: VI] state that on September 30, 1993 the total number of administratively registered private entrepreneurs amounted to $1,191,000$. (This figure means that the number of self-employed grew 18 times in $33 / 4$ years.)

From other statistical data we can follow the number of persons employed in the private sector and the dynamics of both entrepreneurs and employees in greater detail. 
Table 1. Dynamics of the private sector in the Czech Republic in the first wave of privatisation

\begin{tabular}{lccc} 
Category of & Number of employees & \multicolumn{2}{c}{ Indices $(1990=100)$} \\
enterprise & per firm in 1992 & 1991 & 1992 \\
\hline Individuals & 1.04 & 315 & 804 \\
Their employees & & 369 & 1843 \\
Companies & 14.03 & 172 & 457 \\
Their employees & & 500 & 1667 \\
\hline
\end{tabular}

Source: [Machonin 1993b: 20; Tuèek 1993a: 19]

The statistical data encompass four different enterprise types. In most cases, the registered individual entrepreneurs have another primary economic activity and the private undertaking is performed only as a part-time activity. According to our calculations, once this group is subtracted, the total number of registered self-employed drops to approximately 500,000 people (more than $10 \%$ in our stratification survey from April, 1993). [Data 1993] Among them, the majority represent people working, individually or with the assistance of one or two people, as small tradesmen or craftsmen. Only a small proportion of them belong to the emerging group of medium-scale entrepreneurs, while only a very small number of domestic and foreign entrepreneurs have large amounts of capital. Private enterprise is mostly concentrated in four branches: manufacturing, construction, business services and the retail trade. Generally speaking, services and commerce dominate in comparison to material production. (Thus, the privatisation process is contributing to desirable changes in the branch structure of the economy.)

As far as the voucher method - a hitherto prevailing method of privatisation of large enterprises - is concerned, its significance during its first phase seemed to be more psychological and political. It is likely that only a minority of the millions of people who have or will get the very cheap vouchers will become shareholders in the current sense of the word.

Of course the voucher privatisation caused immediate changes in the legal forms of capital ownership. Economically active respondents in the stratification survey in April 1993 declared the following ownership structure of organisations in which they were employed: state owned $60.5 \%$, communal $2.7 \%$, co-operative $6.6 \%$, in the process of privatisation $2.8 \%$, post-privatisation $7.9 \%$, private from beginning/domestic capital $15.9 \%$, private from beginning/partly foreign capital $1.7 \%$, private foreign capital $0.5 \%$, other $1.4 \%$ (It is quite possible that some respondents did not even notice that their firms were ,under privatisation“) [Data 1993]. For the time being, the voucher privatisation has mostly led only to the first steps in the direction of the crucial changes concerning the real disposal of economic sources. In spite of the economic statistics declaring the majority of the GNP as being produced in the private sector, the process aiming to change the formal large-scale privatisation acts into practically-operating, private decision-making is in its initial phases.

We believe that at the present time, a battle is going on, the outcome of which will decide which of the following groups will be successful in obtaining the decisive positions in individual former state enterprises (now formally privatised joint-stock companies): the privatisation investment funds (an unexpectedly strong by-product of the voucher privatisation disposing of $72 \%$ of the investment points in the first wave [Havel 
1993: 15] and with approximately 60\% in the second), in most cases with their background in financial capital; domestic financial capital directly; the present managers; present or former state bureaucrats, eventually professional politicians; foreign capitalists and/or managers; or some outside lobbies of multifaceted character, often combining people from the other groups. The financial capital, in its manifold institutional form and with its well-known monopolistic tendencies, seems up to now to have been the likely victor in this battle. Probably only limited space will remain both for the medium-scale entrepreneurs who emerged in the first wave of privatisation as well as for the groups of shareholders recruited from amongst employees. In any case, the battle is not yet over and the sociological characteristics of the future large-scale capitalists in the Czech Republic are still unclear.

The sum of the enumerated processes represents an analogy of the primary accumulation of capital and a renewed creation of classes and subclasses of large- and middle-scale capitalists, small entrepreneurs, and eventually also of employees involved in enterprise on a part-time basis. While in general, the process is moving relatively rapidly, the crucial changes - the emergence of a relatively large middle class and particularly that of a capitalist economic elite - are only in their initial phases. It is not yet clear how long this will take; what obstacles it will meet; what part of the economy will remain in the hands of state; what the forms of co-existence of the diminishing state and the growing private sector will be; how intensively and in what forms the state will intervene in the formerly state-owned privatised sector; and what the social profile of the new classes will be.

At this point, it should be noted that the process of primary capital accumulation and the emergence of new classes based on private property in this country is not only asserting itself in pure and „noble“ forms: during the last four years many fortunes have been made by illegal and/or immoral means. A certain role has been played by the laundering of money acquired partly in the communist past, partly in recent years from both domestic and foreign sources. In addition to this, there are also illegal foreign currency manipulations; tax swindles; smuggling and other criminal activities; abuse of power positions for personal enrichment; corruption and many methods of accumulating capital in an undercapitalised country. For a sociologist, the main point regarding these issues is not a juridical or moral condemnation of indisputable social facts. Another question is important: how will people who acquired their capital by such means uphold the meritocratic criteria of qualification, performance and lasting market success in subsequent periods with a normally functioning and legally controlled economy? What will the share of people with these kinds of ,qualifications, in the new classes of private proprietors be? What sort of behaviour can the other social classes and the democratic state expect from them?

From the empirical basis which has been briefly reproduced here, by extrapolating with some qualitative limitations (most importantly, the lack of disposable capital and appropriate skills) and with the help of analogies with the pre-war situation, Tuèek [1993a: 24-26] made an estimation of the expected development of class structure based on ownership relations. His figures were repeatedly corrected with, among other sources, the data from the stratification survey in April 1993 [Data 1993]. 
Table 2. The expected development of class structure based on ownership in the Czech Republic in \%

\begin{tabular}{lrr} 
Class category & 1993 & 2005 \\
\hline Middle-scale entrepreneurs* & 0.5 & 2.5 \\
Small entrepreneurs** & 9.7 & 13.5 \\
Members of co-operatives*** & 6.6 & 5.0 \\
Employees in the private sector $\dagger$ & 23.2 & 55.5 \\
Employees in the state sector $\dagger$ & 60.0 & 23.5 \\
\hline
\end{tabular}

*) The large-scale entrepreneurs will represent only a very small number and are therefore not included as a separate category in this table.

**) Including private farmers.

***) Although the final destiny of the co-operative sector is not yet certain, the economic reality leads to the conclusion that it will be necessary to count on its prolonged existence.

$\dagger)$ The estimate of the share of private and state (including communal) sector is based on a radical alternative of privatisation outlined by economists. [Sojka et al. 1993: 64].

The expectation sketched in the table is based on a rough estimate and has an illustrative function. On the other hand, we sought to be realistic in our estimation of the future, particularly as far as the percentages of the entrepreneurs are concerned. And exactly this circumstance turns our attention to the obvious fact that only a minority will be able, in the end, to form the core of the new classes, the existence of which will be based on private property. The large majority of the population will remain in the ranks of both non-manual and manual working people. The overwhelming majority of them will ultimately be employed in the private sector, while only a minority will work in the cooperative sector, eventually in the remainder of the state sector. Once the younger population abandon their illusions as to the possibilities of rapid enrichment for all, the main problem of the future will arise: what will the relationships between the proprietary classes and the rank and file working people be like? Will they once again become the permanently conflictual relations solved by the "class struggle“, or can they be handled in the civilised form of a social partnership in a democratic society? A great deal depends on the solution to this problem, since employed people will, in any case, form the majority decision-makers in democratic electoral voting.

As in other countries, the problem of class relations will be somewhat eased by the objective differentiation within the group of employees. This aspect is better reflected by the schemes arising from neo-Weberian class concepts. Using data collected in the early 1990s, Tuèek [1993a: 26-28] made an estimation of the development in this particular field, which has been corrected by taking into account the figures from the 1993 stratification survey [Data 1993]. 
Table 3. Expected development of the refined class structure in the Czech Republic in \%

\begin{tabular}{lrr} 
Class category & 1993 & 2005 \\
\hline Higher professionals & 9.9 & 12.5 \\
Lower professionals & 16.0 & 15.0 \\
Routine non-manual & 15.7 & 15.5 \\
Self-employed with employees & 2.6 & 4.0 \\
Self-employed without employees & 7.6 & 12.0 \\
Manual supervisors & 2.2 & 2.3 \\
Skilled workers & 16.0 & 16.2 \\
Semi-skilled and unskilled workers & 25.5 & 18.5 \\
Farmers and agricultural workers & & \\
incl. manual members of agricultural co-operatives & 4.5 & 4.0
\end{tabular}

This illustrative table presents a realistic picture of the possible changes in the character of work and qualifications, showing a large decline in the manual labour-force among employees from $54 \%$ in 1993 to $48.8 \%$ in 2005, which would represent a substantial step towards the modernisation of both the economy and the educational structure in the Czech lands.

Class changes represent only one of the important aspects of the social hierarchy. Another is connected with the concept of social stratification. Stratification is conceived of here as the congruence of several important partial social status hierarchies, particularly in education and qualifications, in occupational positions, in income and wealth. The level of such congruence, i.e. of general social status consistency, is a crucial indicator of the level of assertion of meritocratic principles in the analysed society.

What do we know about this issue in the Czech lands? First, we have a precise partial analysis in one of the background studies [Matijù 1993]. On the empirical basis of longitudinal research, data on parents of randomly selected eighth graders (from 1989) were collected at the beginning of 1989 and in the spring of 1992. In this way, important social status indicators of a part of the middle generation (those aged 40-50) have been revealed, enabling some generalisations to be made concerning this group. Having used a series of sophisticated methodological instruments, the author of the background study comes to the conclusion that the post-communist transformation in the Czech lands is leading to a growth in inequality, particularly in terms of income. Two upward mobility channels are important: private entrepreneurship, both full-time and part-time, and political or bureaucratic careers. The two main factors improving chances for upward mobility are tertiary education and prior membership in the old "cadre" structure which has previously accumulated social, political, and perhaps also economic capital at its disposal. From this, the author concludes that the transformation is substantially increasing the role of traditional meritocratic criteria in determining one's position in society and that this process will significantly reduce status inconsistency typical to state socialism. On the other hand, he notes quite strong tendencies in those who profited most from the communist regime to convert political and social capital accumulated in the course of the communist era into economic capital and power under new conditions. This process may not be always compatible with the overall tendency of the society towards increased meritocracy and universalism. As has been already stated, a similar danger for 
the progress of meritocracy may be connected with ,illegal and/or immoral“ methods of acquiring economic capital, regardless of the political appurtenance of people thus engaged. Otherwise, these two phenomena overlap in practice.

Data characterising another aspect of mobility changes in the years 1988-1993 on a sample of all economically active people are also available [Data 1993]. In our case mobility on a nine degrees scale of work complexity constructed by Machonin, Tuèek and Kuchaø is analysed on a representative sample of 2687 respondents. On a five degree scale created for statistical reasons (in order to obtain sufficiently frequented categories) seven stability / mobility patterns were identified by cross-tabulations with some important variables.

Table 4. Social identification of the economically active, stable or mobile in work complexity $(1=$ the highest, $5=$ the lowest $)$ in $\%$

\begin{tabular}{|c|c|c|c|c|c|c|c|c|c|}
\hline \multirow{2}{*}{$\begin{array}{l}\begin{array}{l}\text { Mobility/ } \\
\text { stability }\end{array} \\
\text { A. Upward } \\
\text { to } 1,2 \quad 5.3\end{array}$} & \multicolumn{2}{|c|}{ Gender } & \multicolumn{2}{|c|}{ Age } & \multicolumn{2}{|c|}{ Education } & \multicolumn{2}{|c|}{$\begin{array}{l}\text { Self-emp- } \\
\text { loyment }\end{array}$} & \begin{tabular}{|l} 
Commmu- \\
nist Party
\end{tabular} \\
\hline & $M$ & 59.6 & $\begin{array}{l}-30 \\
30-40\end{array}$ & $\begin{array}{l}19.1 \\
39.7\end{array}$ & $\begin{array}{l}\text { Tert. } \\
\text { Sec. }\end{array}$ & $\begin{array}{l}23.4 \\
39.7\end{array}$ & Yes & 42.4 & \begin{tabular}{lr}
1988 & 22.0 \\
Excl. & 4.3 \\
Left $89+$ & \\
\multicolumn{2}{c}{19.1}
\end{tabular} \\
\hline $\begin{array}{l}\text { B. Upward } \\
\text { to } 3,4\end{array}$ & & & -30 & 20.4 & Elem. & 20.5 & Yes & 30.0 & \\
\hline $\begin{array}{l}\text { C. Stable } \\
\text { on } 1,2 \quad 22.5\end{array}$ & $M$ & 58.2 & $50+$ & 26.7 & $\begin{array}{l}\text { Tert. } \\
\text { Sec. }\end{array}$ & 35.1 & & & 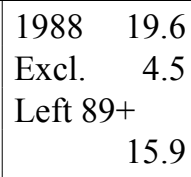 \\
\hline $\begin{array}{l}\text { D. Stable } \\
\text { on } 3,4 \quad 42.9\end{array}$ & M & 56.8 & & & Voc. & 62.9 & No & 85.9 & $\begin{array}{l}\begin{array}{l}\text { Non- } \\
\text { Comm. }\end{array} 88.7\end{array}$ \\
\hline $\begin{array}{l}\text { E. Stable } \\
\text { on } 5\end{array}$ & F & 59.9 & & & $\begin{array}{l}\text { Voc. } \\
\text { Elem. }\end{array}$ & $\begin{array}{l}52.4 \\
40.5\end{array}$ & No & 87.3 & $\begin{array}{l}\begin{array}{l}\text { Non- } \\
\text { Comm. }\end{array} \\
92.3\end{array}$ \\
\hline $\begin{array}{l}\text { F. Downward } \\
\text { to } 2,3 \quad 2.9\end{array}$ & $M$ & 68.5 & & & $\begin{array}{l}\text { Tert. } \\
\text { Sec. }\end{array}$ & $\begin{array}{l}41.1 \\
49.3\end{array}$ & Yes & 46.5 & $\begin{array}{lr}1988 & 31.5 \\
\text { Left } 89+ \\
& 23.3 \\
1993 & 8.2\end{array}$ \\
\hline 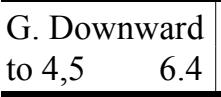 & $F$ & 51.1 & \begin{tabular}{|l|}
-30 \\
$30-40$ \\
\end{tabular} & $\begin{array}{l}17.0 \\
41.5 \\
\end{array}$ & & & & & 1993 \\
\hline Total 100.0 & $\begin{array}{l}\mathrm{M} \\
\mathrm{F}\end{array}$ & $\begin{array}{l}54.0 \\
46.0\end{array}$ & \begin{tabular}{|l}
-30 \\
$30-40$ \\
$50+$
\end{tabular} & $\begin{array}{l}11.2 \\
32.2 \\
20.1\end{array}$ & $\begin{array}{l}\text { Tert. } \\
\text { Sec. } \\
\text { Voc. } \\
\text { Elem. }\end{array}$ & \begin{tabular}{l|}
13.5 \\
29.2 \\
45.2 \\
13.5
\end{tabular} & $\begin{array}{l}\text { Yes } \\
\text { No }\end{array}$ & $\begin{array}{l}13.0 \\
87.0\end{array}$ & $\begin{array}{lr}1988 & 13.9 \\
\text { Excl. } & 2.9 \\
\text { Left } & 10.3 \\
1993 & 3.2\end{array}$ \\
\hline
\end{tabular}

Compared with the analysis of the sample limited to the middle generation, these data show that the factors influencing the upward mobility operate with less intensity among the population as a whole. In spite of the highest probability of upward mobility and 
retention of the previous higher positions for the tertiary educated, their participation in the upward movement to the higher degrees contributes only $23.4 \%$ of all moving in this direction, while that of the secondary educated $39.7 \%$, and even that of qualified workers $32.6 \%$. The meritocratic tendency seems to be only very slight. In addition, not only tertiary, but also secondary educated people have the possibility of above average upward mobility. Chances of upward mobility among the tertiary educated are attended, at the same time, with chances of the same group of downward mobility paths (equally as in the case of new entrepreneurs and young people). Some slightly better position of males could be expected, although this might become a factor stimulating the feminist movement in the future.

The most interesting finding is the relevance of differentiation in the positional and mobility chances among Non-Communists and different groups of Communists. The data show that the assumption of using social, cultural and economic capital accumulated in the old regime in favour of the Communist „cadres" is valid above all for those former Communists (not obligatory „cadres") who proved their high adaptability by an open abandonment of the previous political and ideological orientation and, apparently, by endorsing quite contradictory orientations. As the examples of the groups F and G show, former and particularly present Communists also participate to a higher than average extent in downward mobility.

In spite of all the mentioned reservations, the analysis of the „fresh" data in principle corroborates the conclusions of Matijù concerning the stimulating roles of higher education, self-employment (small-scale entrepreneurs are represented more than in the sample average) and the formerly acquired political capital in individual careers typical for the first phase of the post-communist transformation.

Another way to reproduce the historical changes in social stratification is through the comparison of statistical or sociological data collected toward the end of the communist era with data collected on newly created representative samples during the first phase of the post-communist transformation. The first attempt on these lines has been presented in one of the background studies for the project ECE 2000 [Veèerník 1993a]. The author compares official Microcensus data characterising income distribution in the year 1988 with the results of his surveys (based on quota sampling) that were carried out in December 1991, June 1992, and January 1993. After careful statistical analysis he comes to the following conclusions: a) in all the indicators of income used, i. e. individual net earnings, net household income and per capita income, there was a remarkable increase in inequality between the years 1988 and 1993, particularly favourable to the top tenth; b) as far as factors determining income differentiation are concerned, the significance of traditionally strong demographic factors such as gender, age and number of family members have remained dominant thus far. Behind this, both the earnings inequality of educational levels and of various types of ownership are increasing. The percentage of variance unexplained by statistical and sociological variables is, however, intensifying at this particular time. This phenomenon can be interpreted as a consequence of the emergence of new, non-traditional factors connected with the market economy. Thus, for example, the importance of segments crystallising around dynamic sectors such as foreign trade, banking, the automobile industry, catering, etc. is coming into force. 
In order to contribute to the discussion concerning optimism or scepticism in respect to the increasing role of education in the course of the transformation, we will use a third additional source [Data Stratification 1993].

Table 5. Multiple Regression of Earnings in 1984 and 1993

(Values of Beta Coefficients)*

\begin{tabular}{llllll}
\multicolumn{1}{c}{$1984 * *$} & \multicolumn{3}{c}{$1991 * * *$} \\
\hline Gender & 0.50 & Gender & 0.38 & Gender & 0.34 \\
Age & 0.21 & Education & 0.16 & Education & 0.25 \\
Education & 0.20 & Managerial position & 0.16 & Self-employment & 0.18 \\
Managerial position & 0.17 & Self-employment & 0.16 & Managerial position & 0.17 \\
& & Age & 0.07 & Father's education & 0.07
\end{tabular}

\begin{tabular}{llll}
\multicolumn{1}{c}{1993 Males } & \multicolumn{2}{c}{1993 Females } \\
\hline Managerial position & 0.21 & Education & 0.35 \\
Self-employment & 0.20 & Self-employment & 0.18 \\
Education & 0.20 & Managerial position & 0.15 \\
Father's education & 0.09 & Age & 0.08 \\
& & Father's Education & 0.07
\end{tabular}

*) Earnings have been transformed into logarithmic values.

**) [Data 1984], $\mathrm{N}=1459$.

***) [Data 1991], $\mathrm{N}=1090$.

†) [Data 1993], $\mathrm{N}=2858$.

As the table shows, the influence of demographic factors on the distribution of incomes, very strong under the egalitarian state-socialist system, has actually declined in the course of the transformation; however, that of gender remains the strongest factor, even at present, while that of age is still significant among the female population. The influence of managerial positions is relatively high and stable, particularly among men. The „explanatory power" of formal education (in all three cases closely correlated with work complexity, and therefore not included in the analysis) declined in 1991 in comparison to the 1980s and is increasing at present, particularly amongst the female population. The new factor of self-employment, i. e. the emerging nucleus of the classical class structure, has become one of the significant factors determining the earnings distribution among both men and women. Its connection with „meritocratic“ factors such as education and work complexity is thus far questionable; however, as the mobility analysis provided above has shown, it does not exclude future development. The crucial problems the character of the ongoing de-equalisation remain unsolved for the time being and will only be solved in the future.

Regardless of the possibility of varying interpretations of disposable data, it is quite clear that the differentiation in incomes increased in the first phase of the transformation, particularly in the years 1992 and 1993. Parallel to this, it is obvious that a deep differentiation in the amount of fortunes emerged as a relatively new phenomenon. All this occurred against a background of rapid decline in the average standard of living in the years 1990 and 1991, this being connected with the first steps of the economic reform and with important new phenomena on the international scene (the split of the East European market, a new wave of world recession and, subsequently, the split of 
Czechoslovakia). In 1992 and 1993 the standard of living rose gradually, as the figures concerning incomes show. By a recalculation of data from current statistics [Pøehled 1993: VIII], we obtain the following indices of real incomes: $1989100.00 ; 199098.77$; $199174.25 ; 1992$ 78.64; and for the three quarters of 1993 approximately 82.93.

During this same period, the gradual character of the economic reform, the development of the private sector, and the active employment policy of the government has contributed to maintaining the level of unemployment at an incredibly low level for the time being [Veèerník 1993b: 16-29]. Furthermore, different indicators of poverty reveal that the relative amount of poverty in the Czech Republic compared with the situation in other European countries has thus far remained low [Veèerník 1993b: T. 6]. It is one of the main consequences of the careful social policy of the Federal and Czech governments in recent years, as has been described in [Veèerník 1993b].

A very important aspect of the social changes are the changes in their perception, i.e. in attitudes and value orientations accompanying the objective developments of class structure and stratification [Tuèek 1993b; Hampl 1993; Machonin 1993b: 32-36]. As these questions are not the focus of this article, we will limit ourselves to summarising the new knowledge gained in this field.

Considering all the data collected in surveys on attitudes and public opinion it seems likely that a growing minority of about $25-40 \%$ of the adult population in the Czech Republic has developed which actively supports the privatisation process (partly through personal engagement in it). More than half acknowledge the capitalist, i. e. the class character of this process, and a majority, ranging as high as two thirds, of the population tolerate such changes. At the same time, the remainder regards privatisation with some suspicion, with a large majority declaring themselves for some state intervention in the economy, at least in the form of control over private enterprise. Besides some polarisation of the society on this issue, one can also clearly see the residue of the somewhat inconsistent opinions of a great number of people who still wish to combine the real or assumed advantages of both capitalism and socialism in the spirit of state patriarchalism and egalitarianism. The pro-reform attitudes are much stronger in the Czech lands than in any other post-communist country, a fact which will facilitate the further progress of the post-communist transformation as an objective process.

\section{The exchange of the political elites}

All the changes in the Czech political sphere that have occurred over the years 1989-1994 have led to the installation of a parliamentary democratic system in place of the old totalitarian one. There is no doubt that these changes have been based on a step by step exchange of the political elite, with some elements of circulation [Szelényi, Treiman 1991]. (This is, however, not the case with the economic and cultural elites, where the tendency to continue the careers started in the communist system is much stronger.) In the first period of transformation (until the first democratic elections in 1990, the „government of national understanding“ excluded only obviously compromised people of the old regime from the political elite and allowed many former Communists and functionaries of the non-communist „National Front“" parties of the 1980s to take part in political life, particularly within state administration.

The position of the old political „cadres“ weakened with the return of reform Communists from the 1960s who had been excluded from the Communist Party in the 
year 1970 and, as a rule, had been persecuted by the old regime. Most of them are elderly and have not returned to the Communist Party. Especially those active in dissident circles have taken advantage of the opportunities available in the renewal of political life, and have participated in parties or movements across the political spectrum. From the very beginning of the political changes a very important and, in many respects decisive, role was played by the non-communist wing of the dissent. A section of this group, also mostly elderly, have prolonged their political activities in various political parties and movements (except the Communist Party) or as independent politicians. Most representatives of both wings of the dissent reached the zenith of their political careers in the second period of transformation (until the second free elections in 1992), in connection with the Civic Forum government. The present Czech president, Václav Havel, continues his political activity primarily as a symbol of the moral values typical of the dissent.

Even during the pre-electoral campaign of 1990, a new wave of zealous political activists emerged. At that time, they belonged mostly to the younger middle generation, and came from all parts of the Czech Lands. As a rule, they had not been active in dissent, nor had they been persecuted by the old regime, but felt tied to their careers and to the further improvement of their standard of living under communism (in the ,second society"). They sought a decisive break in the lines of continuity with the reform attempt of the Prague Spring and a new era of development that would give them and their contemporaries enough space. Fascinated with the life-styles of advanced Western countries, they willingly accepted the advice and slogans of a group of somewhat older neo-liberals who had only partly been engaged in the anti-Communist dissent. They first joined the Civic Forum, becoming its candidates in the parliamentary and local elections. A number of them were oriented toward upwardly mobile careers not only in politics, but also, simultaneously, in the economy. This new sector of the political elite gradually strengthened, won the battle concerning the character of the economic reform, formed the basis of the new right-wing parties, and managed to win the elections in 1992 in the Czech lands. Simultaneously, a similar generational shift occurred in the ranks of the democratic left and in the small centrist parties, a highly likely occurrence also in some extreme right-wing parties and to some extent also within the Communist Party.

The most significant part of the political elite of dissident origins which participated in the November 1989 „Velvet Revolution“ remained faithful to its original centrist humanist and liberal democratic conceptions. However, against the background of rapid social and political differentiation, their somewhat abstract and vague slogans were not accepted by the voters. In the 1992 elections, the electorate did not support the Civic Movement and, in fact, excluded most representatives of this group, including the former reform Communists, from the political elite, thus leaving the Movement without parliamentary representation.

The generational shift within the political elite was accomplished later with the decision of the Czech parliament not to give those already-elected members of the federal parliament from the Czech lands seats in the yet-to-be-created second Chamber - the Senate. Only a relatively small group of older experienced people now operate as prominent figures on the political scene. Their active role in politics is connected mainly with their positions in the Czech government and the leadership of political parties and coalitions. 
As result of these processes and against the background of ongoing social and political polarisation, a real exchange of political elites occurred. They now comprise mainly people who belong neither to the ruling nor to the oppositional political elites from the communist system. The former Communists now participating in politics, did not for the most part belong to the real political elites of the old regime. They are simply using the social and cultural capital accumulated in lower positions within the Communist system for careers in the present system.

Further development in political elites will depend mainly on the recruitment of young people and on their political attitudes. For the time being, attitudes favourable to the liberalising changes in the relatively small group of young political activists seem to prevail. The future will depend on the success or failure of the transformation process as a whole and on the dominant mood among the young generation in connection with this.

The main consequence of the hitherto mentioned political processes has been a significant shift in power. The political monopoly of the Communist Party was replaced by the democratically-elected, moderately right-wing government. It includes the representatives of four right-wing parties. In addition to the extreme Communist left and the extreme right, the democratic left (above all, the Social Democrats) and the small centrist liberal democratic parties have also not been included in the ruling coalition, and remain in opposition. The shift in political power is crucial and indicates that, in fact, the transition from a totalitarian to a pluralist democratic system has been completed in the Czech lands.

The existence of a democratic coalition on the one hand, and of a democratic opposition on the other, indicates that the system of parliamentary democracy in the Czech Republic is doing quite well. It has shown, even in moments of extraordinary clashes, a sufficient ability to achieve, pragmatic and compromise solutions where necessary. In spite of its radical economic programme and political rhetoric, the rightwing coalition government has shown, on many occasions, that in practice it employs more gradual approaches based on delaying the resolution of conflictual problems, thus allowing for inevitable social and political compromises. Although both in reality and in the attitudes of the population some differentiation and even polarisation is occurring, for the time being a democratically-acquired social consensus on major problems does exist in the Czech Republic.

\section{Further developments}

Keeping in mind both the international empirical and theoretical „provision“ of models for future development in countries passing through qualitative societal changes analogous to ours [Machonin 1993a: 4.2.; 1993b: 56-62], we will now try to formulate the main types and subtypes (alternatives and variants) of possible future social and political development, given the objective and subjective conditions of Czech society.

If we take into consideration all the specificities of Czech society, we can remove the following items from the list of possible trends for further developments in the postcommunist countries:

a) the reconsolidation of the state socialist system with, at most, only minor alterations;

b) an authoritarian and populist solution for the problems connected with the eventual, resumption of the extensive industrial development; 
c) the installation of an authoritarian and populist regime of nationalist, racial or religious character;

d) a jump into the post-industrial and/or so called post-modern era without accomplishing the main modernisation processes, including those of the meritocrization of the social and economic relations and the rationalisation and democratisation of the political and administrative systems;

e) the restoration of economic and social relationships that had already been overcome before February 25, 1948.

The reason for reducing the list of possibilities by these items is provided on the one hand by the apparent absence of conditions that would enable and/or require similar solutions, and on the other by the absence or presence of only very faint signs of the existence of objective or subjective trends heading in these directions.

One cannot absolutely exclude the possibility that, as a consequence of the substantial changes in international relations, some elements of these „unrealistic“ trends could be introduced the Czech situation under pressure from abroad. The experiences of the years 1918, 1938, 1945, 1948, 1968 and 1989 witness the fact that, as a rule, major European or world shifts in power cause very deep changes in the Czech lands. However, the present situation does not indicate a tendency to a significant change of that kind within the time horizon of our prediction.

With the elimination of these types of future development that simply do not fit Czech conditions, some „realistic“ ones remain that correspond with the Czech specificities and, therefore, find some basis in the existing objective and subjective trends described by our previous analyses. Thus we can speak about existing trends or tendencies, models for the future, the social and political actors who aim to push through changes in corresponding directions, and finally about the different programmes and strategies of the actors. We term all of these phenomena here „social and political“, as each of these tendencies and strategies have their own social background, represent the interests of certain existing or newly emerging social groups and both propose and attempt to assert a definite model of social arrangements. At the same time, each stimulates the existence and activities of differing social movements and associations among others, political parties - applying ideologies, programmes and strategies, partly already elaborated in the past, either in foreign or in domestic conditions. Political parties are trying to obtain or maintain political power in order to realise their programmes. In view of these complex interrelations, we can give the possibilities for future development simple names that can be drawn from the international vocabulary of political science and/or political practice, having in mind not concrete political parties or movements, but rather principal ideological and political orientations. Each of these has, at the same time, a certain social background and social and economic programme.

According to previous analyses [Machonin 1993b: 43-49, 67-75], the following possibilities for the future social and political development of the next decade exist currently in the Czech lands:

a) liberal democratic changes with conservative modifications;

b) liberal democratic changes with welfare state modifications;

c) liberal democratic changes ,without attributes“; 
d) populist changes combined with leftist authoritarianism;

e) populist changes combined with rightist authoritarianism.

These are the principal Czech possibilities for the very near future. Now we must evaluate the probability of their realisation. In order to do so, we will use both election results and the data from public opinion polls as well as our knowledge of the social and political differentiation of the Czech population and of their corresponding attitudes. According to this evidence, with their emphasis on the role of state order, the conservative liberal democrats, have the greatest chance of asserting themselves in the Czech Republic in the very near future.

The expected heightening of social conflict in the further stages of economic reform - the continuing real privatisation, the emergence of classes based on significant differentiation in fortunes and incomes, bankruptcies, increasing unemployment and continuing economic recession - may, in the slightly more distant future, strengthen tendencies toward the welfare state and social democratic modifications to liberal democratic development. This kind of development would correspond to the ongoing polarisation of the society. In comparison with the chances of the conservative right and their allies on one hand and those of the social democrats and their potential allies on the other, the chances of the centrist ,pure" liberal democrats (not to speak of the chances of the extreme left or right) are substantially lower.

If the leading political forces of the government face this situation calmly and do not react by abandoning their tried and true gradual and compromise solutions, and if the socially-oriented forces use democratic means and social negotiations as the main instrument of solving social conflicts, then social peace could be preserved, even in such conditions. A possible by-product of this scenario would be a certain strengthening of the political centre.

If the ruling political structure is not able to avoid the temptation of employing undemocratic measures (e. g. under pressure of radical rightists from within their own ranks), and the social democrats and their allies use populist approaches (abandoning liberal democratic principles), then radicals on both the left and the right will strengthen their positions, social conflicts will intensify and the social and political centre will become weaker still.

Which of the objectively given and subjectively more or less distinctly expressed social and political tendencies (alternatives and variants for future development) are desirable for the Czech Republic with regard to its admission to the European Community? The crucial point in answering this question is the selection of criteria for justifying the options.

The collapse of the communist system was largely connected with its inability to continue the modernisation of Czech society and satisfy the needs of the population in terms of freedom, living standards, life-style, level of civilisation and culture and rational administration. Therefore, in our desire to join the European Community, we have to look for a social and political system that will facilitate a gradual rise to the level of the modern, advanced European societies in all these parameters. The main qualities of such a system must be contrary to the outdated principles on which state socialism was built. The new society requires a pluralist democratic system with a rational administration instead of a totalitarian and bureaucratic system. It requires an effective, meritocratic system of work compensation and job allocation in order to stimulate the performance of 
both individuals and enterprises in the markets for goods, services, capital and labour. Hence, the post-communist transformation requires democratisation and meritocratisation as its two functionally-connected major directions of development. Only the balanced implementation of both can improve the population's quality of life and help in securing a better position for the Czech Republic in relation to advanced Europe.

Unlike the advanced, economically and socially stabilised and balanced Western societies, under the Czech conditions of deep and rapid social change, in which there has been a serious delay in meritocratisation as compared with democratisation, the danger of conflict between these two processes exists. Such a conflict could lead to the misuse of democracy to block meritocratisation through populist measures, or to ill-conceived undemocratic (i. e. authoritarian) ways of implementing radical economic change as an end in itself, and against the will of the majority of population.

It is a very narrow road leading to balanced progress for both democracy and meritocracy: the road of a well-conceived and cautious policy based on the continual renewal of democratic social consensus for the progressing economic changes. This policy is incompatible with either left or right populism and authoritarianism, both of which could only lead to a restoration of totalitarianism and egalitarianism, regardless of the differences in slogans and rhetoric. Such an orientation of development would lead to a prolongation of the societal collapse in civilisation and culture.

From this point of view, the five ,realistic“ possibilities for social and political development open to us two major alternatives: a) extremist populist and authoritarian solutions that do not lead to substantial societal change (the radical leftist and rightist approaches merely being two different variants of this alternative); b) the three other tendencies that all are relatively democratic and lead to the progress of meritocracy which, in reality, means drawing closer to the European Community. From this point of view it is not so important which of the three variants of the second alternative (the conservative, centrist or welfare-state version of liberal democratise) will win in the next or subsequent elections and assert itself in the social reality. In the end, the voters will decide according to their experience of the achieved social changes and the subjective performance of the political parties and leaders in question. In addition to this, neither the objective nor subjective, neither the international nor domestic conditions of the postcommunist transformation in the Czech lands are hugely accommodating of widely differing solutions that would really lead to the preferred end of joining the European Community. This is likely the reason why in practice many political subjects choose stepby-step and compromise strategies that are not fully compatible with their own ideologically defined goals. One could even say, after considering all the difficulties awaiting us, that a compromise combination or even a combination of the strategies based on the three mentioned social and political orientations would be useful for the Czech Republic.

If, from this view-point, we evaluate the two possible and more or less probable paths of development in the global, social and political situation of the Czech Republic as outlined above, we can only formulate one recommendation, based on our analysis. The more goodwill in maintaining social peace and achieving a consensus among the democratic social and political forces, the more likely the Czech Republic's progress will be in a direction favourable for admission to the European Community, the more likely 
will be the decisive defeat of the forces pulling the country back and the more successful the real post-communist transformation of Czech society.

PAVEL MACHONIN led a team that in 1967 carried out the first representative sociological survey on social stratification and mobility in Czechoslovakia. (The results of the survey were published in 1969 in the book Czechoslovak Society.) After an enforced break in research activities, he returned to his work at Charles University in 1990. At present, he is working at the Institute of Sociology of the Academy of Sciences. His main research field is the ongoing social transformation of Czech society. He has published a new study Czechoslovakia's Social Structure on the Eve of the Prague Spring 1968 (1992) as well as a number of articles in the Czech Sociological Review.

\section{References}

Data 1984. Class and Social Structure. Survey IFS CS AS. Prague: IFS CS AS.

Data 1991. Social Transformation. Survey ISPS CU - IS CS AS. Prague: IFS CS AS.

Data 1993. Social Stratification and Mobility in Eastern Europe after 1989. Comparative survey UCLA - IS AS CR. Prague: IS AS CR.

Hampl, S. 1993. Attitudes of Population in the Czech Republic. Background Study. Prague: IS AS CR.

Havel, J. 1993. Behaviour of Subjects: Privatisation in the Czech Republic 1990-1993. Background Study. Prague: IS AS CR.

Machonin, P. 1992. „Political and Economic Transition or Social Transformation?“ Sisyphus 8: 129-133.

Machonin, P. 1993a. General Approaches to the Problems of Post-Communist Social Transformation. Background Study. Prague: IS AS CR.

Machonin, P. 1993b. Post-Communist Transformation in the Social and Political Sphere in the Czech Republic. Thematic Study. Prague: IS AS CR.

Machonin, P. 1993c. „The Social Structure of Soviet-Type Societies, its Collapse and Legacy.“ Czech Sociological Review 1: 231-249.

Matijù, P. 1993. Winners and Losers in the Transformation. Background Study. Prague: IS AS CR.

Müller, K. 1993. Scenario of Transformation of Science, Technology and Education in Czech Republic. Thematic Study. Prague: IS AS CR.

Pøehled ukazatelù sociálního a ekonomického rozvoje ÈR 1993/4.

Sojka, M. et al. 1993. Economic Scenario. Thematic Study, first draft. Prague: IS AS CR.

Szelényi, J., D. J. Treiman 1991. „Vývoj sociální stratifikace a rekrutace elit ve východní Evropi“ [The Development of Social Stratification and the Recruitment of Elites in Eastern Europe.] Sociologický èasopis 24: 276-298.

Tuèek, M. 1993a. Social and Class Structure of Society in the Czech Republic and its Predicted Development up to 2005. Background Study. Prague: IS AS CR.

Tuèek, M. 1993b. Popular Attitudes towards the Transformation of Czech Society. Background Study. Prague: IS AS CR.

Veèerník, J. 1993a. Changing Income Distribution and Prospects for the Future. Background Study. Prague: IS AS CR.

Veèerník, J. 1993b. Social Problems and Social Policy. Background Study. Prague: IS AS CR. 